\title{
Role of Legislature in Sustainable Agricultural Development in Developing Nations: A Case Study of Nigeria
}

\begin{abstract}
Akinbode Michael Okunola*
Department of Economics and Commerce, God's Vision Academy, 27409 Agodi Nigeria A R T I C L E I N F O

Article history:

Received 29 September 2015

Accepted 23 April 2016

Available online, ISSN: 2148-127X

Keywords:

Agriculture

Programs

\section{A B S T R A C T}

When continuity is lacked in the agricultural programs and policies of a developing nation, such nation cannot avoid to keep moving round a circle. Such nation's agricultural sector will be full of activities without actions and achievements will elude such country. This study therefore reviewed some of the agricultural programs and policies in Nigeria, their failures and successes as well as reasons behind the failures and success vis-à-vis the recent agricultural development strategy of Nigeria; Agricultural Transformation Agenda which has had its attending major successes of lifting the agricultural economy of Nigeria from being a democratic dividend to profit-oriented commercial business sector of the economy and $\mathrm{x}$-rayed the role of legislature in sustainability of the successes of the agricultural strategy for continuity of agricultural development in Nigeria.
\end{abstract}

Policies

Legislature

Transformation-Agenda

"Corresponding Author:

E-mail: okunolaakinbode@gmail.com

\section{Introduction}

Agriculture is one of the most important sectors of the economies of developing countries of the world. The growth of this sector is, however, not in consonant with its strategic importance in the economies of various countries (Ogbonna, 2011). For example, in Nigeria, the growth of the agricultural sector has declined drastically since independence with the contribution of agriculture to the national economy dropping from $80 \%$ in the 1960 s to a mere $34 \%$ in 2003 (Chigbu, 2005). Conscious of the strategic importance of agriculture in the economy, the Federal Government of Nigeria (FGN) has formulated and implemented national agricultural programs aimed at boosting agricultural production since independence in 1960. The effectiveness or otherwise of the implementation of some selected past national agricultural programs shall be used as lessons to provide solution(s) to this backward movement results despite forwardmovement lofty programs and policies the government of Nigeria has undertaken especially as there is a new government and change of administration has been a regular cause for failures of programs in Nigeria.

A policy is a deliberate plan of action to guide decisions and achieve rational outcomes It is also a guideline consisting of principles and rules governing the behavior of persons in an organization. Policies prescribe how people in an organization should act or behave (Asiabaka, 2002). Policy differs from rule of law. While law can compel or prohibit behaviors, policy merely guides actions toward those that are most likely to achieve a desired outcome. Agricultural policy is a statement of action and a fundamental tool employed in achieving agricultural development (FBN, 1997). A program, on the other hand is a comprehensive plan that includes objectives to be attained, specifications of resources required and stages of work to be performed (Asiabaka, 2002). Elaborate plans are called programs (Kirkpatrick, 1987). According to Olatunji (2005), a program is a collection of coordinated activities that are mutually directed towards the attainment of a definite goal and it usually comprises of several segments or projects which can be separately pursued as a component of the whole. The concept of program implies that a goal is in focus and several activities would be needed and coordinated to attain the goal.

In Nigeria agricultural policies and programs have undergone changes especially in the postcolonial era. These changes have been a mere reflection of changes in government or administration (Amalu, 1998). This is because these policies and programs vary only in nomenclature and organizational network. They emphasize almost same objectives like: to provide food for the inhabitants of the nation (food security and sufficiency) and export excess to other countries and to provide rural dwellers and farmers with extension 
services, agricultural support and rural development services etc. Despite all the policies and laudable programs with challenging themes, Nigeria is yet to achieve food security. Agriculture also continues to suffer from inertia associated with these policies and program reformation that pervade Nigeria.

\section{A Brief History of Some National Agricultural Programs}

According to Jibowo (2005), some national agricultural programs that were established and implemented following Nigeria's political independence in 1960 and the subsequent establishment of the Federal Ministry of Agriculture in 1970 included:

\section{National Accelerated Food Production Program $(N A F P P)$}

This program was established in 1972 , following the end of the Nigerian civil war and the need to end the food crisis that engulfed the nation at that time. The program was designed with the basic aim of increasing food production and general agricultural productivity through famers' education on effective and efficient methods of agricultural production that increases output and productivity. The failure of this program was due to: the cost-sharing arrangement that involved the farmer in the last two phases of the program; farmers who were not members of cooperative societies were left out; unceremonious withdrawal of funding of the cooperative societies by the Federal Government; and demonstration trials that did not give a true reflection of the technology that was introduced (Iwuchukwu and Igbokwe, 2012).

\section{River Basin Development Authorities (RBDAs)}

This national agricultural program came into existence in 1973 as a result of Decree 25 of 1976 . Its aims and objectives included the provision of irrigation facilities through construction of dams for all year-round agricultural production, provision of potable water to people in the rural areas for increased agricultural production, assisting to bring more land under cultivation by increasing the farm size of the small scale farmers through the provision of land clearing services using government tractor hiring services at minimum charges, construction of feeder roads to the rural areas for good transportation. There are 11 RBDAs still existing till date.

\section{Agricultural Development Projects (ADPs)}

The Agricultural Development Projects came about in 1975, after a bilateral agreement between the Federal Government of Nigeria and the World Bank. The two basic aims and objectives the ADPs were meant to achieve included increased food production and the raising of income of the small scale farmers with the ultimate goal of improving their living standard and welfare. Initially, nine pilot (enclave) ADPs, covering a few local government areas, were established in nine states of the federation. Successful implementation of the project gave rise to the establishment of ADPs in all the states in the country.

\section{Operation Feed the Nation (OFN)}

The Operation feed the Nation was launched in 1976. The aims and objectives of the program included, among others: to convince Nigerians that farming was not a dirty job; to put into effective use some of the findings that have accumulated in universities and research institutes over the years; to encourage domestic food production by traditionally non-food producing sectors of the economy; to encourage the spirit of self-sufficiency and national self-reliance in food production as well as improve the feeding habits of Nigerians by encouraging good nutritional habits. Some of the problems of this program were: indiscriminate use of land for farming activities; most of the participants were very young and inexperienced and without the fundamental knowledge of farming; hired labor was the main source of labor employed by participants; there was absence of readily available markets for the produce of the program and livestock diseases caused havoc on farms of the novice farmers. This program is no more existing.

\section{Agricultural Credit Guarantee Scheme (ACGSF)}

The ACGSF was established by Decree No 20 of 1977 and started operations in April, 1978. The Federal Government holds $60 \%$ and the Central Bank of Nigeria $40 \%$ of the shares. The Fund guarantees credit facilities extended to farmers by banks up to $75 \%$ of the amount in default net of any security realized. The Fund is managed by the Central Bank of Nigeria which handles the day-today operations of the Scheme. Between 1978 and 1989 when the government stipulated lending quotas for bank under the Scheme, there was consistent increase in the lending portfolios of banks to agriculture. This agro-credit program is still in existence.

\section{Green Revolution}

The Green Revolution took off in 1980. The aims and objectives were also not much different from those of the OFN. Using subsidy of the prices of agricultural inputs and machineries, including improved seeds, agrochemicals, among other incentives, the government encouraged farmers to produce food, cash crops, as well as livestock, massively. The program did not achieve its objective of increasing food supply because there was delay in execution of most of the projects involved in the program as well as no monitoring and evaluation of the projects for which huge sums of money were spent (Iwuchukwu and Igbokwe, 2012).

\section{Nigerian Agricultural Insurance Scheme (NAIS):}

According to Akinrinola and Okunola (2014), in the 1985 budget, $20 \%$ of the 1.06 billion naira total capital allocation went to agriculture. To tie down this bogus allocation, the government introduced an agriculture insurance scheme. Nigerian Agricultural Insurance Company was incorporated on the 1st of June, 1993 by the enabling Decree 37 of 1993. The Nigerian 
Agricultural Insurance Scheme was designed to benefit the small, medium and large scale farmers. The scheme was designed specifically to: promote agricultural production; boost farmers' confidence in adoption of new technology; provide financial support to farmers in the event of losses arising from natural disasters; increase the flow of agricultural credit from lending institutions to the farmers; minimize or eliminate the need for emergency assistance provided by Government during period of agricultural disasters. The scheme is still in operation.

\section{Directorate of Food, Roads and Rural Infrastructure (DFRRI)}

DFRRI was established in 1986. The aims, objectives and functions of the directorate among others included to: identify, involve and support viable local community organizations in the effective mobilization of the rural populace for sustainable rural development; identify and support the production of food and fiber crops; construct, rehabilitate and maintain rural feeder roads to facilitate food production and rural development. The problems of the program included poor quality of infrastructures provided by the directorate; mismanagement of funds; lack of proper focus and program accountability (Idachaba, 1988). This program is no more existing.

\section{National Fadama Development Project (NFDP)}

In 1992 the Federal Government of Nigeria in conjunction with the World Bank established the National Fadama Development Project. The scheme was designed to improve the flooded plains of the savannah (Fadama). This led to the development of small irrigation pumps and shallow tube wells for small scale irrigation farming system (SSIFS). The success of Fadama I led to the establishment of Fadama II and the last Fadama III. Overall appraisal of the first, second and third phases of the project showed remarkable success. Fadama III, the last phase of the program came to an end in December, 2013.

National Special Program for Food Security (NSPFS):

This program was launched in 2002. The aim of the program was to attain food security and alleviate rural poverty in Nigeria. It aimed at helping farmers to increase output and income, strengthen extension service delivery and promote simple farm technologies. Setbacks associated with the program were seen in the inability of majority of the beneficiaries to repay their loan on time, complexity and incompatibility of innovation and difficulty in integrating technology into existing production system (Iwuchukwu and Igbokwe, 2012). This program is also no more existing.

\section{Failed Programs}

With the exception of National Fadama Development Project (1992) whose three phases ended, achieving significantly its aims and objective, the following programs failed to achieve the reasons for which they were developed:
- National Accelerated Food Production Project (NAFPP, 1972)

- Operation Feed the Nation (OFN, 1976)

- Green Revolution Program (1980)

- Directorate of Food, Roads and Rural Infrastructure (1986)

- National Special Program for Food Security (2002)

Iwuchukwu and Igbokwe (2012) highlighted some of the reasons for the failure of these programs to be:

\section{Non Interaction Between and Among Stakeholders}

The consequence of non-interaction between and among the relevant agricultural stakeholders within a particular program has been a bane to the progress of such programs. Agriculturists, researchers and more importantly the farmers are normally ignored during planning and implementation of agricultural/rural development policies and programs. These stakeholders are in a better position to identify the policies and programs that will be tailored to the need of the farmers/masses

\section{Weak Agricultural Policy}

Developed economies have their agricultural policies spelt out for the masses and the world to know. This is not the case in Nigeria as can be seen that from $1^{\text {st }}$ October, 1960 to $15^{\text {th }}$ January, 1966, there were several agricultural policies but no agricultural program/project to carry out the directives of the policies. Sometimes, agricultural programs/projects are not consequences of agricultural policies.

Role Conflict between Different Programs and Projects

There was role conflict between DFRRI and ADP in many states. Reports has it that DFRRI merely removed the sign post of some ADPS and replaced it with its own to lay claim to the construction of certain rural roads and borehole (Ayoola, 2001).

\section{Successful Programs}

From the program listed above, the programs that are still existing till date include:

- $\quad$ River Basin Development Authorities (1973)

- Agricultural Development Projects (1975)

- Agricultural Credit Guarantee Scheme (1977)

- Nigerian Agricultural Insurance Scheme (1985)

- National Fadama Development Project (1992) (The last phase Fadama III came to an end, December, 2013)

Hence, from the foregoing it is evident that there are only two reasons these programs have been sustained this far in Nigeria. It is either the program is co-sponsored by the Federal Government of Nigeria and a donor agency like World Bank in the case of Agricultural Development Projects (1975) and National Fadama Development Project (1992) or the use of the instrument of law making 
in the case of River Basin Development Authorities (1973), Agricultural Credit Guarantee Scheme (1977) and Nigerian Agricultural Insurance Scheme (1985). In other words, should the World Bank withdraw its funding of the ADP, collapse is inevitable.

Taking a significant look at the development of agricultural extension in the United States of America, i.e., the University Organized Extension System, how it evolved and how it has been the foundation for some tertiary institutions, the importance of the legislative arm of government of developing nations among whom is Nigeria in sustainable agricultural and rural development cannot be underscored.

\section{University Organized Extension Type}

The term "University Extension" or "extension of the University" was first commonly used in Britain in the 1840s. This was later incorporated into proposals arising from the Royal Commission on the University and Colleges of Oxford (1852), largely arising from the evidence submitted by William Sewell in suggestions for the Extension of the University (1850). The first practical steps were taken in 1867-68 when James Stuart, fellow of the Trinity College, Cambridge, gave lectures to women associations and working men clubs in the North of England. Stuart approached the authorities in the University of Cambridge and appealed to them to organize centers for extension lectures under the University's supervision. Cambridge formally adopted the system in 1873, followed by London University in 1876 , and Oxford University in 1878. By 1880s the work was being referred to as the extension movement. In this movement, the University extended its work to those beyond the campus Ogunfiditimi and Ewuola (1995).

What was meant to be just an extension service in the Great Britain to bridge the gap between the researchers and the farmers became the basis for the establishment of Universities in the United States. This was only made possible because of the legislative framework that was provided for the extension movement which clearly protected it, expanded its scope and made it flexible to be a guide for the establishment of research institutions which later developed to Universities for researches instead of just been a service.

For 20 years prior to the first introduction of the bill in 1857, there was a political movement calling for the creation of agricultural colleges. The movement was led by Professor Jonathan Baldwin Tuner of Illinois College. For example, the Michigan Constitution of 1850 called for the creation of an "agricultural school", though it was not until February 12, 1855, that Michigan State Governor signed a bill establishing the United States' first agricultural college, the Agricultural College of State of Michigan, known today as Michigan State University which served as a model for the Morrill Act.

The University organized extension systems is the product of three legislative acts passed in the United States of America between 1862 and 1914. It started with the passing of the Land-Grant College Act in 1862, followed by the Hatch Act in 1887 setting up experiment research station and in 1914 by Smith-Lever Act providing for the extension service. With these Acts, federally funded researches, classroom teaching and extension services came into being in the United States. The Morrill Land-Grant College Act granted land to each state for the colleges of agriculture and with the passing of the Hatch Act and the Smith Lever Act, the provision was made for a nation-wide system for state experiment station for carrying the result of research directly to the farmers. Land-Grant Colleges included colleges of agriculture and other institutions that will organize extension services and provide the link between the researchers and the farmers for the development of agriculture. Most of the Land-Grant Colleges are now universities. Some of these include University of Maryland, Cornell University, State Agricultural College and Model Farm (which is now Lowa State University of Science and Technology) among others.

From the foregoing, the progress of the extension movement which eventually gave birth to various Universities was possible due to the active roles of the legislature in the provision of legal framework and not just a mere political jamboree of a particular government which would have died since the day the government ended. Between 2010 and 2015 in Nigeria, the agricultural policy that guided and aided the activities in the agricultural and rural development sector of the nation's economy was the Agricultural Transformation Agenda.

\section{Agricultural Transformation Agenda}

"The vision in the transformation strategy is to achieve a hunger-free Nigeria through an agricultural sector that drives income growth, accelerates achievement of food and nutritional security, generates employment and transforms Nigeria into a leading player in global food markets to grow wealth for millions of farmers" (Agricultural Transformation Agenda, 2011 Draft). To achieve successful implementation of the policy, the following objective were set out among others:

- There shall be an end to the era of treating agriculture as a development project

- There shall no more be any isolated projects without a strategic focus to drive agricultural growth and food security in a clear and measurable way.

- Agriculture will focus on as a business

- The transformation of the agricultural sector will be utilized to create jobs, create wealth and ensure food security

- Value chains will be focused where Nigeria has comparative advantage

\section{Transformation Policies}

According to the policy document, to achieve the transformation agenda in the agricultural sector, restructuring of fertilizer procurement and distribution, 
financial value chains and agricultural investment framework would take place:

Fertilizer strategy: The fertilizer strategy is to stimulate a thriving private sector fertilizer industry, with government getting out of fertilizer procurement and distribution, supporting farmers through smart subsidies. The involvement of private sector becomes necessary sequel to inefficiency in the government distribution system and wastage of resources.

Growth enhancement support scheme (GESS):The Growth Enhancement Support Scheme (GESS) was designed to move subsistence farmers from their high poverty level through market oriented surplus facilitated by Nigerian Incentive Based Risk Sharing for Agricultural Lending (NIRSAL). Growth Enhancement Support investment that commenced by 2012 was targeted at twenty million farmers by 2020 where a group of farmers would be supported for four years. Investment is expected to generate five times to ten times returns in increased production. The twenty million farmers would be in four groups and the program would also be four phases.

Improving investment frameworks for agriculture: In order to further provide an enabling environment for the private sectors, improving investment frameworks for agriculture was also conceived. This would be achieved through the development of Staple Crop Processing Zones (SCPZ). The SCPZ would focus on attracting private sector agribusinesses to set up processing plants in zones of high food production, to process commodities into food products. The government will enable this by putting in place appropriate fiscal, investment and infrastructure policies for staple crop processing zones.

\section{Successes of the Agricultural Transformation Agenda}

Agricultural sector in Nigeria's economy received a major attention from 2010 to 2015. There was and still a need to take the economy of the nation away from dependence on crude oil and diversify into other sectors that have the capacity to employ the unemployed youths, ensure rural economy development, food security and make Nigeria self-sufficient. All these will not happen until agriculture becomes a business and not just a democratic dividend. The former Minister of Agriculture and Rural Development, Dr. Akinwumi Adesina who is now the President, Africa Development Bank, a feat based on his success as a Minister in Nigeria, described the ATA of 2010-2015 as Nigeria's equivalent of the "green revolution" that took place in Asia in the 1960s and 1970s, where new highly productive varieties of rice and wheat and the chemical fertilizers that helped them achieve their potential led to a doubling and tripling of yield and self-sufficiency (Vanguard Newspaper, 16/09/2015).

The Growth Enhancement Support Scheme which is responsible for the efficient distribution of subsidized farm inputs has reached 14.3 million farmers out of a targeted 20 million farmers with 1.3 million MT (metric tons) of fertilizer, 102,703 MT of improved rice seeds,
67,991 MT of improved maize seeds, 6,171 MT of improved cotton seeds, 130 million stems of cassava, 45.5 million seedlings of cocoa, 9 million seedlings of oil palm among many other crops between 2012 and 2014. These inputs helped to produce an additional 21 million MT of food that has acted as a buffer against inflation and the devaluation of the naira in 2014. Such increase in food production could be linked with more capital investment made available by lending institutions which increased from $0.07 \%$ in 2011 to $5 \%$ in 2014 . A total of $\mathrm{N} 27.5$ billion was lent to fertilizer and seed companies.

The rice policy under the ATA has brought about an increase in the number of Rice mills needed to produce parboiled rice from one in 2010 to 24 in 2014. Realizing that there is a country-wide demand of an estimated 2.5 million MT of parboiled rice in Nigeria, the Federal Government approved a N9 billion fund to support private sector to acquire nine new 36,000 MT per annum factories to raise the capacity of local production to 1.2 million MT leaving a national supply deficit of 1.3 million MT which would be met by controlled imports. In Oil Palm value chain, a total of 9 million sprouted oil palm nuts were distributed to 45,353 small and large oil palm estate owners between 2013 and 2015. Additional Crude Palm Oil (CPO) production due to these interventions is projected to be 400,000 MT of crude oil palm that is currently being imported. According to the National Bureau of Statistics, agricultural sector grew by $9.19 \%$ (year-on-year) in the third quarter of 2014, up by $2.7 \%$ from the third quarter of 2013. The agricultural sector grew by $38.53 \%$ between third and fourth quarter of 2014 with crop production being the main driver with a growth of $43.5 \%$.

\section{Projections of the Agricultural Transformation Agenda}

Perhaps if one of the problems of agricultural programs and policies in Nigeria which is inconsistency could be dealt with, and the successes achieved so far under the policies and programs structured in the ATA sustained, Nigeria could reach an additional 32 million farmers by 2019 under the Growth Enhancement Support Scheme (GESS), up from the 14.3 million farmers reached with inputs between 2012 and 2014, reaching at least 8 million unemployed youths. Under the ATA, a production of 7.1 million MT per annum rice paddy was achieved. With new investment, milling capacity could rise by 5 million MT and Nigeria will be self-sufficient in rice production by 2017. Cassava processing capacity, currently below 100, 000 MT per annum will be raised to 675,000 MT per annum by 2019. Maize production will increase from the achievement of over 12 million MT per annum in 2014 (compared to 9 million MT per annum in 2011), 18 million MT per annum by 2019.

For Sorghum, Nigeria will go from 9.76 million MT in 2014 to 13 million MT by 2019 to cater for the increase in demand for the malted sorghum and high energy food markets. Nigeria can produce 1.2 million MT of soya beans by 2019, up from 700,000 MT achieved in 2014 
(compared to 500,000 MT in 2011). For cotton, from 240,000 MT per annum in 2014 (compared to 125,000 MT in 2011), there could be an increase to 500,000 MT per annum by 2019, Cocoa production which is at 350,000 MT exported per annum in 2014 could be 700,000 MT exported per annum in 2019, Crude Oil Palm, production of 800,000 MT per annum in 2014 could rise to 1.6 million MT per annum in 2019.

\section{The Role of Legislature in Sustainable Agricultural Development in Nigeria}

Inconsistency in agricultural programs and policies in Nigeria has been the impediment of agricultural progress. Each government comes with its own concepts and does not care about the successes recorded by the previous government nor how to build on or continue from where such government stopped. This lack of continuity has denied Nigeria self-sufficiency in food production and food security. However, with the Nigeria's National Assembly (both Senate and House of Representatives) using the instrument of law to provide legal framework for successful programs and policies, they will no more be a mere political manifesto of the government that designed and implemented them, rather, they would become legal guide for subsequent governments without prejudice to development of new programs and policies.

Nigeria's agricultural sector will not develop until continuity of agricultural programs and policies is ensured. Such programs as the Growth Enhancement Support Scheme (GESS) should be provided with a legal framework to protect its existence to achieve its projected improvement. Despite the drastic fall in the price of crude oil which is the main source of revenue for Nigeria from about $\$ 100$ to under $\$ 50$ around the last quarter of 2014 , the prices of staple food items remained relatively stable. This is largely due to the success of the ATA which has ensured increased local production of staple foods and as such importation was used to cater for local supply deficit. Such policies as the Rice Transformation Plan which has increased local rice production, the Fertilizer Distribution System which has removed the bureaucratic bottleneck in the fertilizer distribution chain, all commodities transformation plan and other policies that have contributed to the successes of the ATA in developing Nigeria's agricultural sector sustainably, should be protected by laws. Since they have been tested and they have produced results, the level of successes they have achieved should be made a template for further improvement.

\section{Conclusion}

To be successful, Nigeria's reforms and agricultural programs in particular need to be backed up. It should also be a program selected based on a rational, national and institutional structure that come from a national consensus on how best to achieve sustainable and equitable rural/ agricultural development. Sustainable agricultural development in developing nations like Nigeria should go beyond political manifesto. The governments and heads of African states should embark aggressively on holistic programs that will outlive their tenures by providing legislative framework for the agricultural programs and policies that have proven their worth. There has to be a political will on the part of both the executive and legislative arms of government to ensure a synergized efforts in ensuring that the programs and policies that have been tested and identified to be successful should be protected against discontinuity and somersaults by providing legal frameworks for such programs and policies to ensure continuous growth and development of the sector, food security and selfsufficiency of the country in food production. This will also ensure employment generation in the value chain of agriculture.

\section{References}

Agber T, Iortima PI, Imbur EN. 2013. Lessons from implementation of Nigeria's past national Agricultural Programs for the Transformation Agenda, American Journal of Research Communication, 1(10): 238-253.

Agricultural Transformation Agenda. 2011. We Will Grow Nigeria's Agricultural Sector, Federal Ministry of Agriculture and Rural Development, Abuja Nigeria.

Akinrinola, OO, Okunola Akinbode M. 2014. Evaluation of Effects of Agricultural Insurance Scheme on Agricultural Production in Ondo State, RJOAS, 4(28).

Amalu UC. 1998. Agricultural Research and Extension Delivery systems in Sub Saharan Africa, Calabar: University of Calabar Press.

Asiabaka CC. 2002. Agricultural Extension; a Handbook for Development Practitioners, Omoku, River State: Molsystem United Services.

Ayoola GB. 2001. Essays on the Agricultural Economy 1: A Book of Readings on Agricultural Development Policy and Administration in Nigeria, Ibadan: TMA Publishers.

Idachaba FS. 1988. Strategies for achieving food self-sufficiency in Nigeria", Key Note Address, 1st National congress of science and technology, University of Ibadan: 16th August, 1988.

Iwuchukwu JC, Igbokwe EM. 2012. Lesson from Agricultural Policies and Programs in Nigeria, Journal of Law, policy and Globalization, vol. 5 pp. $11-21$.

Jibowo AA. 2005. "History of Agricultural Extension in Nigeria" In: Adedoyin S.F (ed) Agricultural Extension in Nigeria, ilorin (AESON).

Kirkpatrick TO. 1987. Supervision, Kent Publishing Company, Boston.

Obiora CJ. 2014. Agricultural Transformation Agenda in Nigeria: How Prepared is the Technology Transfer-Sub System?" Journal of Biology, Agriculture and Health care 4(2).

Ogbonna NO. 2011. Level of access to Information Communication Technology among rural farmers in Enugu State, Nigeria", a Masters' thesis, Department of Agricultural Extension, University of Nigeria, Nsukka, Enugu State, Nigeria.

Ogunfiditimi TO, Ewuola SO. (1995), "the Synthesis of Comparative Agricultural Extension Systems, Published by Emmy Press, Ibadan, Nigeria.

Olatunji SO. 2005. Monitoring and evaluation of Agricultural Extension programmes", In; Nwachukwu.I. and Onuekwusi G. (eds.) Agricultural Extension and Rural Sociology. Enugu: Snap press Ltd. 287-306.

Vanguard Newspaper accessed on 16/09/2015. www.Monster.ca accessed 23/05/08. 